Article

\title{
Preparation of $\mathrm{LaXCoO}_{3}(\mathrm{X}=\mathrm{Mg}, \mathrm{Ca}, \mathrm{Sr}, \mathrm{Ce})$ catalysts and their performance for steam reforming of ethanol to hydrogen
}

\author{
Fei Ma a,b, Zhenwu Ding a,c, Wei Chu ${ }^{\text {a,c,*, }}$, Shixiong Hao ${ }^{\text {a,d }}$, Tao Qi ${ }^{b}$ \\ a Department of Chemical Engineering, Sichuan University, Chengdu 610065, Sichuan, China \\ b National Engineering Laboratory for Hydrometallurgical Cleaner Production Technology, Institute of Process Engineering, Chinese Academy of Sciences, \\ Beijing 100190, China \\ c Sichuan Provincial Engineering Technology Center for Environmental Protection Catalytic Materials, Chengdu 610064, Sichuan, China \\ d Department of Chemical Engineering, Sichuan University of Science and Engineering, Zigong 643000, Sichuan, China
}

\section{A R T I C L E I N F O}

Article history:

Received 25 April 2014

Accepted 28 June 2014

Published 20 October 2014

\section{Keywords:}

Citric acid-complexing method

Perovskite

Cobalt

Composite catalyst

Ethanol steam reforming

Hydrogen

\begin{abstract}
A B S T R A C T
Perovskite nanocomposite catalysts $\mathrm{LaXCoO}_{3}(\mathrm{X}=\mathrm{Mg}$, Ca, Sr, or Ce; $n(\mathrm{La}): n(\mathrm{X})=3: 2)$ have been prepared by a citric acid-complexing method and used for steam reforming of ethanol (SRE), leading to hydrogen generation. The samples were characterized by X-ray diffraction, infrared spectroscopy, scanning electron microscopy, X-ray photoelectron spectroscopy, $\mathrm{N}_{2}$ adsorption-desorption, and $\mathrm{H}_{2}$ temperature-programmed reduction. The effects of elemental substitution in the $\mathrm{LaCoO}_{3}$ perovskite were studied, and the catalytic performance and primary stability of the hydrogen production from SRE were investigated. In the highly substituted samples, only the Ce-doped sample was isolated as the pure perovskite phase. The presence of a $\mathrm{Co}_{3} \mathrm{O}_{4}$ phase in the Ca-doped or Sr-doped samples was beneficial for the reduction of the active Co component, while Sr-doped or Ce-doped samples showed good activity and stability. The sample incorporating $\mathrm{Sr}$ demonstrated better catalytic performance than those of other samples.
\end{abstract}

(C) 2014, Dalian Institute of Chemical Physics, Chinese Academy of Sciences. Published by Elsevier B.V. All rights reserved.

\section{Introduction}

Hydrogen is an efficient and clean fuel [1,2] and is considered to be one of a small list of new energies capable of solving the human energy crisis in the 21st century. The rapid development of hydrogen-based fuel cells and fuel cell vehicles has led to an increase in the demand for hydrogen, which will continue to increase in the future. At present, most hydrogen used in industry is derived from fossil fuel reforming and water electrolysis. In these processes, the former consumes fossil fuels, and the latter requires higher energy than it produces. These problems present significant barriers to the widespread application of hydrogen. Because of this, the reforming of lower alcohols has been studied extensively; the steam reforming of ethanol (SRE) has attracted attention because the raw material of $10 \%(\mathrm{v} / \mathrm{v})$ biomass ethanol can be obtained directly from the production industry without distillation. The reaction process is expressed as:

$\mathrm{CH}_{3} \mathrm{CH}_{2} \mathrm{OH}+3 \mathrm{H}_{2} \mathrm{O} \rightarrow 6 \mathrm{H}_{2}+2 \mathrm{CO}_{2} \quad \Delta H^{\theta_{298}}=347.4 \mathrm{~kJ} / \mathrm{mol}$

The SRE to hydrogen is endothermic [3], with complex reactions and numerous by-products, including acetaldehyde, acetone, ethylene, CO, and carbon deposition [4]. Hence, it is particularly important that catalysts have good catalytic performance and high selectivity and stability over the whole process of producing hydrogen from ethanol. According to the literature, many catalysts containing $\mathrm{Ni}[5,6]$, Co [7,8], and other

\footnotetext{
* Corresponding author. Tel: +86-28-85403836; Fax: +86-28-85461108; E-mail: chuwei1965scu@163.com, chuwei1965@scu.edu.cn This work was supported by the National Basic Research Program of China (973 Program, 2011CB201202). 
metals $[9,10]$ in the SRE reaction show superior performance and selectivity. Ni-based catalysts show excellent activity in breaking the $\mathrm{C}-\mathrm{C}$ and $\mathrm{C}-\mathrm{H}$ bonds in ethanol; however, they suffer from significant carbon deposition, while Co-based catalysts exhibit outstanding reforming performance.

Supported on various oxides such as $\mathrm{Al}_{2} \mathrm{O}_{3}$ [11], $\mathrm{SiO}_{2}$ [12], $\mathrm{MgO}$ [13], $\mathrm{CeO}_{2}$ [14], and $\mathrm{La}_{2} \mathrm{O}_{3}$ [15], cobalt has been investigated widely, and $\mathrm{CeO}_{2}$ and $\mathrm{La}_{2} \mathrm{O}_{3}$ have proved to be catalyst supports with excellent activity and desirable reaction products. However, some challenges still exist for the application of Co-based catalysts in SRE because of their low stability, which is caused by the sintering of metallic Co and coke deposition. In particular, higher-content cobalt generally leads to more serious sintering. Rare earth elements on the surface of the supports have been shown to react with $\mathrm{CO}_{2}$ [7] to form carbonate, which could eliminate surface coke. $\mathrm{CeO}_{2}$ can generate lattice oxygen, which reacts with surface carbon deposits to eliminate carbon. Therefore, the supports also play important roles in the SRE reaction [14].

$\mathrm{ABO}_{3}$ perovskite is known to be stable and shows good catalytic activity in many fields. In recent years, researchers have found that perovskites in SRE demonstrate catalytic performance, but the amount of active metal is limited. Therefore, the ability to maximize the use of a metal in a perovskite becomes the most important problem. Partial substitution of the $\mathrm{ABO}_{3}$ perovskite by another metal (alkali metal or rare earth element) at the A site forms $\mathrm{A}_{1-x} \mathrm{~A}_{x} \mathrm{BO}_{3}$-type materials, which can change the oxidation state of the $B$ site ion and the oxygen vacancy density, indirectly affecting the catalytic performance of perovskite.

$\mathrm{LaCoO}_{3}$ perovskite catalyst in SRE does not tend to form $\mathrm{CH}_{4}$ and $\mathrm{CO}$, but its activity is too low, and appropriate substitution at the $\mathrm{A}$ or $\mathrm{B}$ sites is required to improve its catalytic performance [16-20]. Cui et al. [21] found that Ce-doped $\mathrm{LaCoO}_{3}$ perovskite significantly promoted the catalytic performance of the methane combustion reaction. Sr-doped $\mathrm{La}_{1-x} \mathrm{Sr}_{x} \mathrm{MO}_{3}(0<x$ $<0.4, \mathrm{M}=\mathrm{La}, \mathrm{Ca}, \mathrm{Fe}$ ) compares favorably with the noble metal catalyst $0.5 \mathrm{wt} \% \mathrm{Pt} / \mathrm{Al}_{2} \mathrm{O}_{3}$ in the catalytic combustion of methane [22]. The catalytic performance of $\mathrm{Cu}$-doped La$\mathrm{Co}_{1-x} \mathrm{Cu}_{x} \mathrm{O}_{3-\delta}$ perovskite is significantly higher in the synthesis of lower alcohols [23]. Bedel et al. [24] confirmed that in the Fischer-Tropsch (F-T) reaction the peak amount of metallic cobalt, produced by the reduction of $\mathrm{La}_{1-y} \mathrm{Co}_{0.4} \mathrm{Fe}_{0.6} \mathrm{O}_{3-\delta}$ perovskite, could reach $2.1 \%$. $\mathrm{Zn}$-doping of the $\mathrm{LaCoO}_{3}$ perovskite as studied by Chu et al. [7] enhanced the catalytic performance of SRE remarkably.

This paper examines the effect of $\mathrm{LaXCoO}_{3}(\mathrm{X}=\mathrm{Mg}, \mathrm{Ca}, \mathrm{Sr}$, Ce), formed by the substitution of four different metal ions in $\mathrm{LaCoO}_{3}$ at the $\mathrm{A}$ sites, on both the perovskite structure and the valence Co at the B sites. These catalysts were characterized by X-ray diffraction (XRD), infrared spectroscopy (FT-IR), scanning electron microscopy (SEM), X-ray photoelectron spectroscopy (XPS), $\mathrm{N}_{2}$ adsorption-desorption (BET), and $\mathrm{H}_{2}$ temperature-programmed reduction (TPR). The substitution effects of four elements on the $\mathrm{LaCoO}_{3}$ perovskite structure and performance have been studied, and the catalytic performance and stability of the catalysts for hydrogen production by SRE were investigated.

\section{Experimental}

\subsection{Catalyst preparation}

Perovskite composite catalysts, $\mathrm{LaXCoO}_{3}(\mathrm{X}=\mathrm{Mg}$, $\mathrm{Ca}, \mathrm{Sr}, \mathrm{Ce})$, were prepared by the citric acid-complexing method. $\mathrm{La}\left(\mathrm{NO}_{3}\right)_{3} \cdot 6 \mathrm{H}_{2} \mathrm{O}, \quad \mathrm{Mg}\left(\mathrm{NO}_{3}\right)_{2} \cdot 6 \mathrm{H}_{2} \mathrm{O}, \quad \mathrm{Ca}\left(\mathrm{NO}_{3}\right)_{2} \cdot 4 \mathrm{H}_{2} \mathrm{O}, \quad \mathrm{Sr}\left(\mathrm{NO}_{3}\right)_{2} \cdot$ $4 \mathrm{H}_{2} \mathrm{O}, \mathrm{Ce}\left(\mathrm{NO}_{3}\right)_{3} \cdot 6 \mathrm{H}_{2} \mathrm{O}, \mathrm{Co}\left(\mathrm{NO}_{3}\right)_{2} \cdot 6 \mathrm{H}_{2} \mathrm{O}$, and citric acid (CA) were used as reagents. The six metal nitrates, in the required stoichiometric ratios $(n(\mathrm{La}+\mathrm{X}) / n(\mathrm{Co})=1, n(\mathrm{La}) / n(\mathrm{X})=3: 2)$, and citric acid $(n(\mathrm{CA}) / n(\mathrm{M})=1.2)$, were dissolved in deionized water in separate beakers. The appropriate amount of PEG 400 $(n(\mathrm{PEG} 400) / n(\mathrm{CA})=0.2)$ was added to the citric acid solution, and then the metal nitrate solution was added. The mixed solutions were stirred at $80{ }^{\circ} \mathrm{C}$ at atmospheric pressure until a gel formed. This gel was dried in an oven at $120^{\circ} \mathrm{C}$ for $24 \mathrm{~h}$ to give the precursor materials, and these were calcined at $750{ }^{\circ} \mathrm{C}$ for 3 $h$ to obtain the catalyst samples $\mathrm{LaCoO}_{3}, \mathrm{La}_{0.6} \mathrm{Mg}_{0.4} \mathrm{CoO}_{3}$, $\mathrm{La}_{0.6} \mathrm{Ca}_{0.4} \mathrm{CoO}_{3}$, $\mathrm{La}_{0.6} \mathrm{Sr}_{0.4} \mathrm{CoO}_{3}$, and $\mathrm{La}_{0.6} \mathrm{Ce}_{0.4} \mathrm{CoO}_{3}$, which are denoted L-C, L-Mg-C, L-Ca-C, L-Sr-C, and L-Ce-C, respectively.

\subsection{Catalyst characterization}

The crystal phase of the catalysts was measured on a Philips X'pert pro MPD X-ray diffractometer with graphite-monochromated $\mathrm{Cu} K_{\alpha}$ radiation, operating at a voltage of $40 \mathrm{kV}$ and current of $50 \mathrm{~mA}$. The scattering angles were between $20^{\circ}$ and $80^{\circ}$.

The catalysts were also characterized with the TENSOR 27 infrared spectrometer (IR, Bruker, Germany). The catalyst was diluted 100 times with $\mathrm{KBr}$ before being ground and formed into a tablet. These samples were scanned at room temperature (32 scans) from 4000 to $400 \mathrm{~cm}^{-1}$.

The morphologies of the catalysts were recorded using a Hitachi S-3400 field emission scanning electron microscope (FE-SEM) with the accelerating voltage $20 \mathrm{kV}$.

The surface elements of the catalysts were analyzed on a XSAM800 spectrometer (XPS, Kratos, UK) with an Al $K_{\alpha}(h v=$ $1486.6 \mathrm{eV}$ ) X-ray radiation source. Charging effects were corrected by referencing the binding energy of the $\mathrm{C} 1 \mathrm{~s}$ peak from carbon contamination at $284.6 \mathrm{eV}$.

The specific surface area and average pore diameter of catalysts were determined on a NOVA 1000e surface area and pore size distribution analyzer (Quantachrome, USA). The nitrogen adsorption volume of the loaded catalyst (200 mg) was measured with cryogenic liquid nitrogen at $-196^{\circ} \mathrm{C}$. The specific surface area of the catalyst was calculated by the BET equation, and the pore size distribution of catalyst was measured using the BJH model.

For $\mathrm{H}_{2}$-TPR experiment, $\mathrm{H}_{2}$ consumption of catalyst $(50 \mathrm{mg}$ ) was recorded online on an SC-200 gas chromatograph with a thermal conductivity detector (TCD) in a $5 \% \mathrm{H}_{2} / \mathrm{N}_{2}$ gas mixture at a heating rate of $10^{\circ} \mathrm{C} / \mathrm{min}$.

\subsection{Catalyst activity measurements}


The catalytst activity was measured using a fixed-bed microreactor. In each run, the catalyst (100 mg, 60-80 mesh) was diluted with quartz sand ( $800 \mathrm{mg}, 40-60$ mesh) and loaded into the reactor. Prior to reaction, the catalysts were heated to the required temperature in $5 \% \mathrm{H}_{2} / \mathrm{Ar}$ and then cooled to the initial reaction temperature under a flow of $\mathrm{N}_{2}$. A liquid reaction mixture, with a water to ethanol molar ratio of $6: 1$, was fed into the reactor through a DDB-300 electronic peristaltic pump at a rate of $4.8 \mathrm{~mL} / \mathrm{h}$ before mixing with $\mathrm{N}_{2}$ (as a carrier gas, 60 $\mathrm{mL} / \mathrm{min}$ ), and then vaporized at $150{ }^{\circ} \mathrm{C}$. The total space velocity was $50000 \mathrm{~h}^{-1}$. The catalyst reactivity was measured at $600{ }^{\circ} \mathrm{C}$ for $10 \mathrm{~h}$. The reaction products were analyzed online on an $\mathrm{SC}-200$ gas chromatograph with a TCD. $\mathrm{H}_{2}, \mathrm{~N}_{2}, \mathrm{CO}, \mathrm{CO}_{2}, \mathrm{CH}_{4}$, and other permanent gases were separated on a TDX-01 column using $30 \mathrm{~mL} / \mathrm{min}$ pure $\mathrm{Ar}$ as the carrier, while $\mathrm{H}_{2} \mathrm{O}$, ethanol, acetone, and acetaldehyde were separated on a Porapak- $Q$ column.

\section{Results and discussion}

\subsection{The structure and surface elements of catalysts}

\subsubsection{Phase analysis of catalysts}

Figure 1 shows the XRD patterns of the prepared catalysts. All samples shows diffraction peaks attributed to the $\mathrm{LaCoO}_{3}$ rhombohedral crystalline phase. When other elements are substituted into the perovskite, the samples contained hybrid phases. Only the L-Ce-C sample displayed a pure perovskite crystal phase. The characteristic reflection peaks of the $\mathrm{MgCo}_{2} \mathrm{O}_{4}$ phase appeared in L-Mg-C $\left(2 \theta=43^{\circ}\right.$ and $\left.62.5^{\circ}\right)$. A $\mathrm{Co}_{3} \mathrm{O}_{4}$ phase was observed in both L-Sr-C and L-Ca-C $(2 \theta=$ $31.3^{\circ}, 36.8^{\circ}$, and $65.7^{\circ}$ ), but $\mathrm{L}-\mathrm{Sr}-\mathrm{C}$ also contained lanthanum oxide and a strontium carbonate impurity. Figure 1 also shows a shift in the characteristic peaks of the perovskite as different elements were substituted into $\mathrm{LaCoO}_{3}$. Around the characteristic peak of perovskite $\left(2 \theta=33^{\circ}\right)$, the peaks of L-Mg-C, L-Sr-C, and L-Ca-C were slightly shifted to lower angles $\left(-0.1^{\circ}\right)$, while the same peak in $\mathrm{L}-\mathrm{Ce}-\mathrm{C}$ was shifted to a higher angle $\left(+0.3^{\circ}\right)$ Thus, substituting different elements affected the $\mathrm{LaCoO}_{3}$ perovskite structure, of which $\mathrm{L}-\mathrm{Ce}-\mathrm{C}$ had the greatest change. To further investigate, the cell parameters of the samples were calculated and are listed in Table 1.

Table 1 shows that the lattice parameters of L-Mg-C, L-Sr-C, and L-Ca-C are similar or slightly larger than L-C $(0.5436 \mathrm{~nm})$, whereas L-Ce-C is $0.0017 \mathrm{~nm}$ smaller. In terms of ionic radius, $\mathrm{Mg}^{2+}(0.068 \mathrm{~nm})$ and $\mathrm{Ca}^{2+}(0.118 \mathrm{~nm})$ are smaller than $\mathrm{La}^{3+}$ $(0.136 \mathrm{~nm})$. The $\mathrm{Ce}^{3+}(0.134 \mathrm{~nm})$ is quite similar to $\mathrm{La}^{3+}$, and only $\mathrm{Sr}^{2+}(0.144 \mathrm{~nm})$ is larger than $\mathrm{La}^{3+}$. Because of the different ionic radii, substituted elements into the perovskite lattice led to the differences in the lattice parameters $[25,26]$. Although the ionic radius of $\mathrm{Mg}^{2+}$ or $\mathrm{Ca}^{2+}$ is much less than that of $\mathrm{La}^{3+}$, the differences in the lattice parameters between $\mathrm{L}-\mathrm{Mg}-\mathrm{C}$, $\mathrm{L}-\mathrm{Ca}-\mathrm{C}$, and $\mathrm{L}-\mathrm{C}$ are very small. $\mathrm{L}-\mathrm{Mg}-\mathrm{C}$ contains the $\mathrm{MgCo}_{2} \mathrm{O}_{4}$ phase, while $\mathrm{L}-\mathrm{Ca}-\mathrm{C}$ contains the $\mathrm{Co}_{3} \mathrm{O}_{4}$ phase, which indicates that most of the $\mathrm{Mg}$ and $\mathrm{Ca}$ did not enter the $\mathrm{LaCoO}_{3}$ perovskite lattice. L-Ce-C is significantly different from the single crystalline phase, indicating that Ce has more extensively entered the
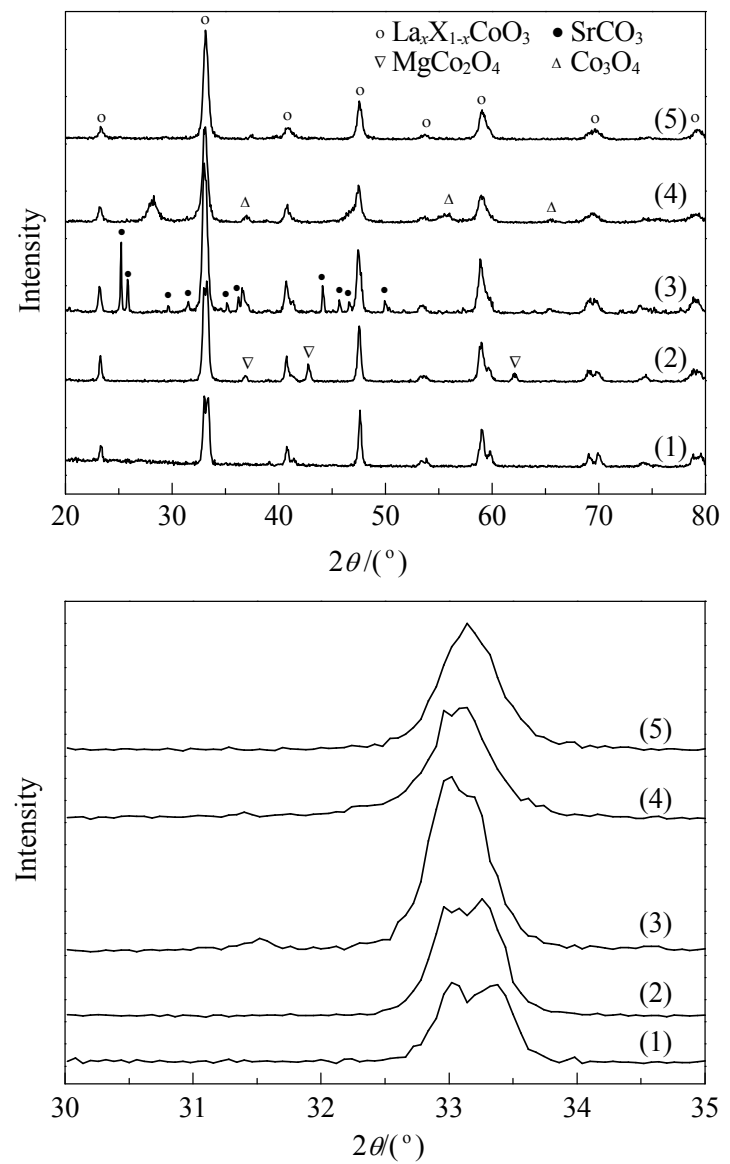

Fig. 1. XRD patterns of the $\mathrm{LaCoO}_{3}$ catalysts with different cations. (1) L-C; (2) L-Mg-C; (3) L-Sr-C; (4) L-Ca-C; (5) L-Ce-C.

perovskite lattice. This is why Ce substitution has a greater impact than $\mathrm{Mg}$ and $\mathrm{Ca}$ substitution on the main structure of the $\mathrm{LaCoO}_{3}$ perovskite [27]. However, the data from the L-Sr-C sample showed the coexistence of an additional phase or phases. To further analyze the influence of substitution on the main structure of the perovskite, more parameters of samples were characterized.

The FT-IR spectra of the prepared samples are displayed in Fig. 2. Two strong bands at around 600 and $420 \mathrm{~cm}^{-1}$ have been assigned to a Co-O [28] stretching vibration and an $0-\mathrm{Co}-\mathrm{O}$ [29] bending vibration from the $\mathrm{CoO}_{6}$ octahedra in perovskite La- $\mathrm{CoO}_{3}$, respectively. As shown in Fig. 2, all the samples contain this structure. A peak at $670 \mathrm{~cm}^{-1}$ was observed in the L-Ca-C and L-Sr-C samples, which has been attributed to the $\mathrm{M}-\mathrm{O}$ stretching vibration in the tetrahedral structure of $\mathrm{Co}^{2+}$ [30]. This $\mathrm{Co}^{2+}$ could be from the $\mathrm{Co}_{3} \mathrm{O}_{4}$ [31], seen in the XRD

Table 1

Physical characters of the catalysts.

\begin{tabular}{lcccc}
\hline Sample & $\begin{array}{c}S_{\text {BET }} \\
\left(\mathrm{m}^{2} / \mathrm{g}\right)\end{array}$ & $\begin{array}{c}\text { Lattice parameter } \\
(\mathrm{nm})\end{array}$ & $\begin{array}{c}\text { Segregation } \\
\text { phase }\end{array}$ & $\begin{array}{c}\text { Crystallite size } \\
(\mathrm{nm})\end{array}$ \\
\hline $\mathrm{L}-\mathrm{C}$ & 8.3 & 0.5436 & - & - \\
$\mathrm{L}-\mathrm{Mg}-\mathrm{C}$ & 3.3 & 0.5435 & $\mathrm{MgCo}_{2} \mathrm{O}_{4}$ & 26.5 \\
$\mathrm{~L}-\mathrm{Ca}-\mathrm{C}$ & 9.8 & 0.5438 & $\mathrm{Co}_{3} \mathrm{O}_{4}$ & 23.5 \\
$\mathrm{~L}-\mathrm{Sr}-\mathrm{C}$ & 9.5 & 0.5442 & $\mathrm{Co}_{3} \mathrm{O}_{4}$ & 20.3 \\
L-Ce-C & 6.8 & 0.5419 & - & - \\
\hline
\end{tabular}




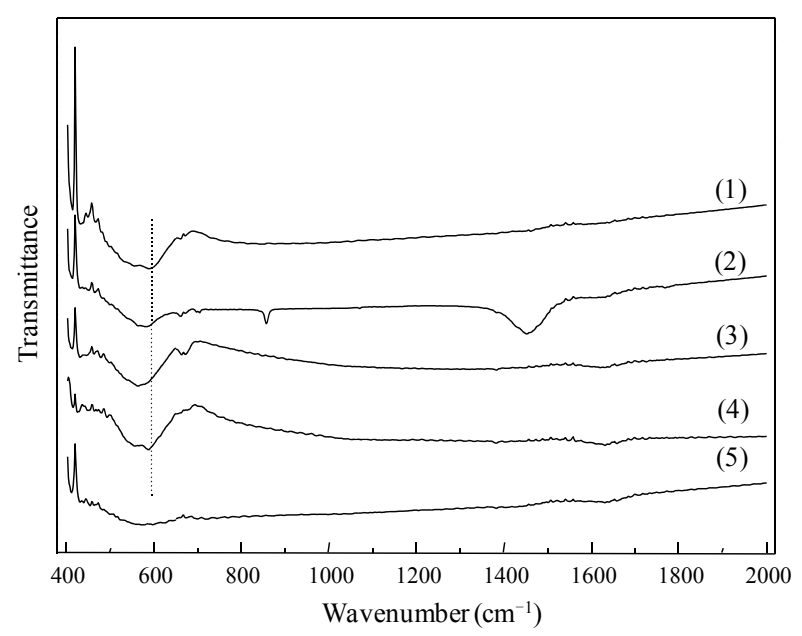

Fig. 2. FT-IR spectra of the $\mathrm{LaXCoO}_{3}(\mathrm{X}=\mathrm{Mg}$, Ca, Sr, Ce) samples. (1) L-C; (2) L-Sr-C; (3) L-Ca-C; (4) L-Mg-C; (5) L-Ce-C.

data. $\mathrm{A} \mathrm{CO}_{3}{ }^{2-}$ peak at around 1470 and $814 \mathrm{~cm}^{-1}$ was observed in the $\mathrm{L}-\mathrm{Sr}-\mathrm{C}$ sample (the $\mathrm{C}-\mathrm{O}$ stretching and $\mathrm{C}-\mathrm{O}$ bending vibrations at 1476 and $844 \mathrm{~cm}^{-1}$, respectively), indicating that carbonate is present in $\mathrm{L}-\mathrm{Sr}-\mathrm{C}$, which is consistent with the XRD results. Compared with the $\mathrm{L}-\mathrm{C}$ data around $600 \mathrm{~cm}^{-1}$, the vibration peaks of L-Mg-C, L-Ca-C, and L-Ce-C are shifted to a low wavenumber, among which $\mathrm{L}-\mathrm{Ce}-\mathrm{C}$ shows the largest change and is further evidence of the larger substitution into the perovskite structure.

Table 1 displays the specific surface area of the samples. From these results, the specific surface area of the samples is quite small, less than $10 \mathrm{~m}^{2} / \mathrm{g}$, which is due to the high calcination temperature. This high temperature is required for the formation of the perovskite structure. The specific surface area of L-Mg-C was the smallest of the five samples $\left(3.3 \mathrm{~m}^{2} / \mathrm{g}\right)$, and those of the L-Sr-C $\left(9.5 \mathrm{~m}^{2} / \mathrm{g}\right)$ and L-Ca-C $\left(9.8 \mathrm{~m}^{2} / \mathrm{g}\right)$ samples

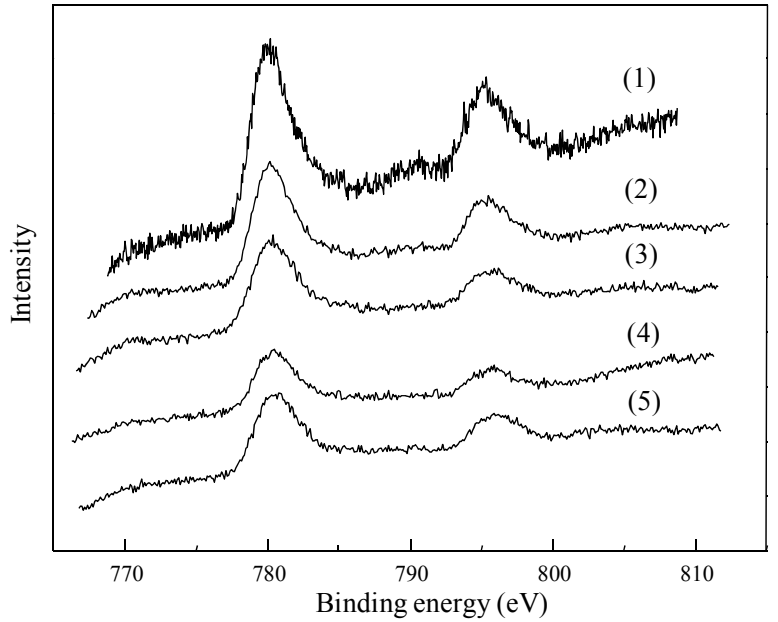

Fig. 4. XPS Co $2 p$ spectra of the five samples. (1) L-C; (2) L-Ce-C; (3) L-Sr-C; (4) L-Ca-C; (5) L-Mg-C.

were slightly larger than the L-C sample $\left(8.3 \mathrm{~m}^{2} / \mathrm{g}\right)$, while the specific surface area of L-Ce-C was lower than the L-C sample.

\subsubsection{The morphologies of catalysts}

To show the effect of different element substitutions on the surface morphology, SEM images of the new samples are shown in Fig. 3. L-Mg-C and L-Ca-C have a surface morphology similar to the L-C sample. However, L-Mg-C has a smaller specific surface area due to a denser surface morphology. L-Sr-C and L-Ce-C had a similar structure to that of L-C perovskite, but L-Sr-C had a new acicular phase and L-Ce-C had a bulk crystal phase, embedded on the perovskite structure.

\subsubsection{Surface properties of the catalysts}

The Co $2 p$ spectra of the five catalysts are shown in Fig. 4. The samples exhibited similar XPS spectra to the perovskite
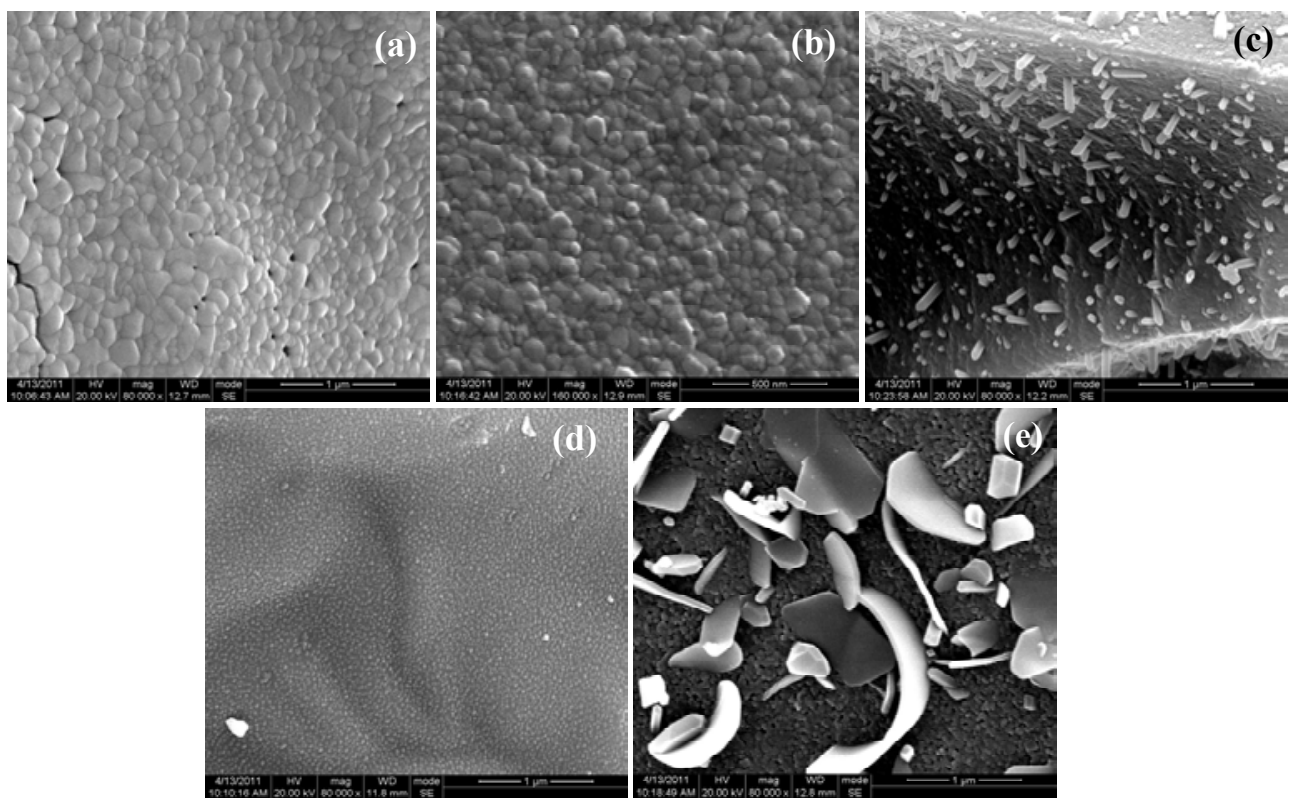

Fig. 3. SEM images of the five samples. (a) L-C; (b) L-Ca-C; (c) L-Sr-C; (d) L-Mg-C; (e) L-Ce-C. 
Table 2

Surface atomic ratios and binding energies of catalysts.

\begin{tabular}{|c|c|c|c|c|}
\hline \multirow{2}{*}{ Sample } & \multicolumn{2}{|c|}{ Atom concentration (at\%) } & \multirow{2}{*}{$\mathrm{Co} / \mathrm{La}$} & \multirow{2}{*}{$\begin{array}{c}\text { Co } 2 p_{3 / 2} \\
(\mathrm{eV})\end{array}$} \\
\hline & $\mathrm{La}$ & Co & & \\
\hline $\mathrm{L}-\mathrm{C}$ & 6.81 & 3.58 & 0.53 & 780.0 \\
\hline L-Mg-C & 8.18 & 10.61 & 1.29 & 780.8 \\
\hline L-Ca-C & 9.26 & 8.30 & 0.90 & 780.6 \\
\hline L-Sr-C & 4.59 & 8.23 & 1.79 & 780.6 \\
\hline L-Ce-C & 6.67 & 15.01 & 2.25 & 780.3 \\
\hline
\end{tabular}

$\mathrm{LaCoO}_{3}$. As shown in Table 2, compared with the L-C sample, the Co $2 p_{3 / 2}$ peak of the four substitution catalysts are shifted to higher binding energies, indicating that the charge on the cobalt had changed. The $\mathrm{Co}^{3+}$ binding energy in $\mathrm{MgCo}_{2} \mathrm{O}_{4}$ is $780.8 \mathrm{eV}[32,33]$, and in the L-Mg-C sample, the Co $2 p_{3 / 2}$ peak was $0.8 \mathrm{eV}$ higher than $\mathrm{LaCoO}_{3}$, which is mainly due to the inclusion of the $\mathrm{MgCo}_{2} \mathrm{O}_{4}$ phase. For the $\mathrm{L}-\mathrm{Ca}-\mathrm{C}$ and $\mathrm{L}-\mathrm{Sr}-\mathrm{C}$ samples, the Co $2 p_{3 / 2}$ peak shifted to a higher energy by $0.6 \mathrm{eV}$ because of the presence of the $\mathrm{Co}_{3} \mathrm{O}_{4}$ phase. The binding energy was $0.3 \mathrm{eV}$ higher in the $\mathrm{L}-\mathrm{Ce}-\mathrm{C}$ sample [27]. From the ratio of $\mathrm{Co} / \mathrm{La}$, the substitution of $\mathrm{Sr}$ or Ce into the sample increased the content of the surface cobalt in the catalyst, which should increase catalytic activity.

\section{2. $\quad$ TPR results}

The $\mathrm{H}_{2}$-TPR profiles of the catalysts are shown in Fig. 5. At
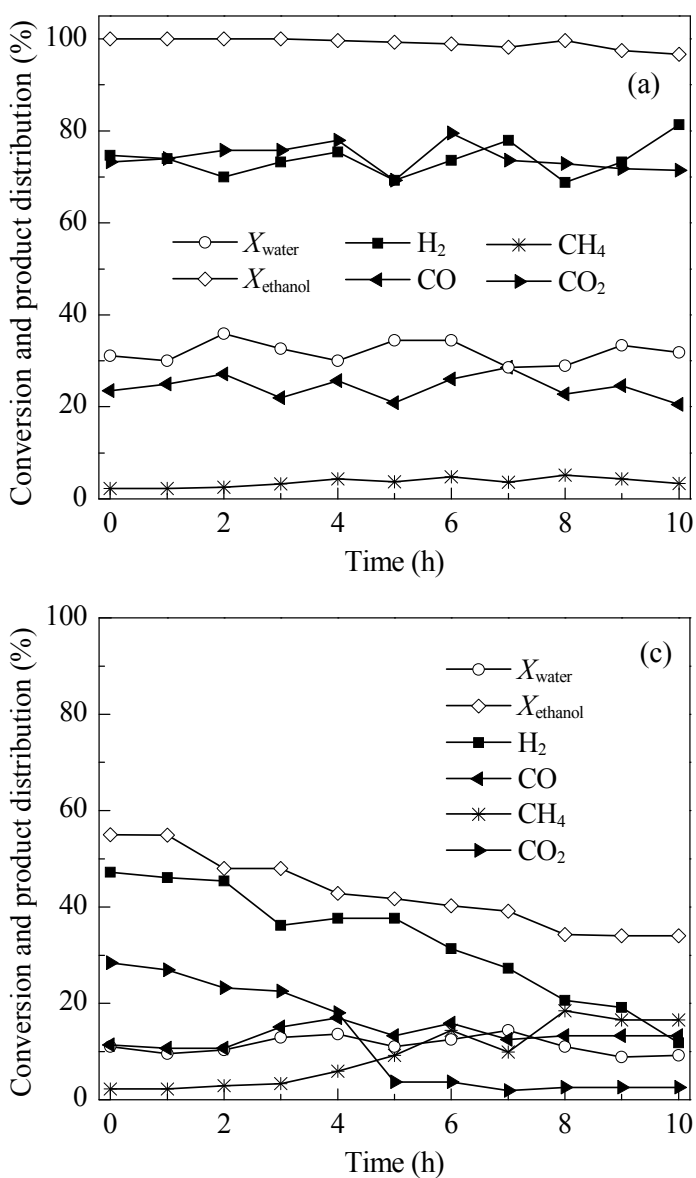

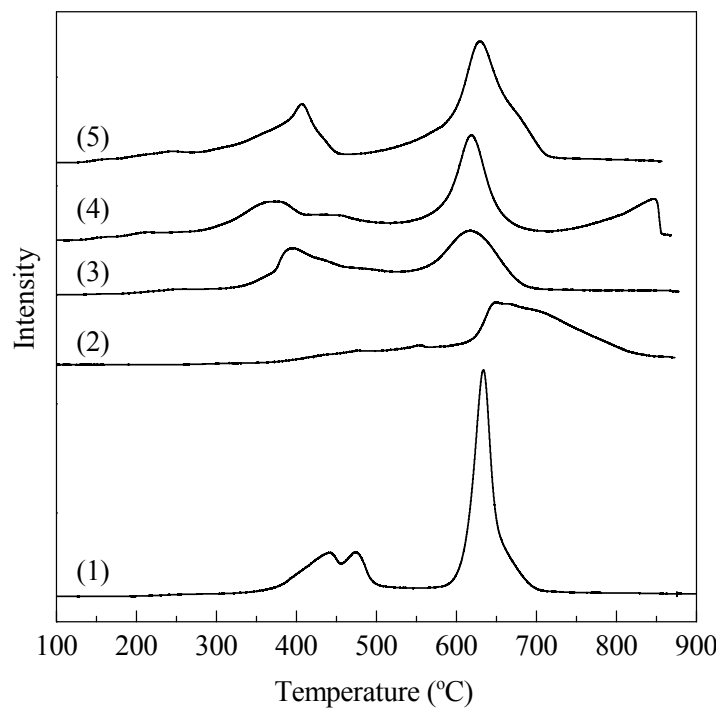

Fig. 5. $\mathrm{H}_{2}$-TPR profiles of the $\mathrm{LaXCoO}_{3}(\mathrm{X}=\mathrm{Mg}, \mathrm{Ca}, \mathrm{Sr}, \mathrm{Ce})$ catalysts. (1) L-C; (2) L-Mg-C; (3) L-Ca-C; (4) L-Sr-C; (5) L-Ce-C.

least two reduction peaks are observed for the catalysts except for L-Mg-C. Relative to the L-C sample, the first reduction peaks of the $\mathrm{Ca}$, Sr, and Ce-substituted samples are shifted to lower temperatures, thus the La-O-Co interaction is weaker, which therefore lowered the energy of the cobalt reduction. Because of the partial reduction of $\mathrm{Co}^{3+}$ to $\mathrm{Co}^{2+}$ [7], the first reduction
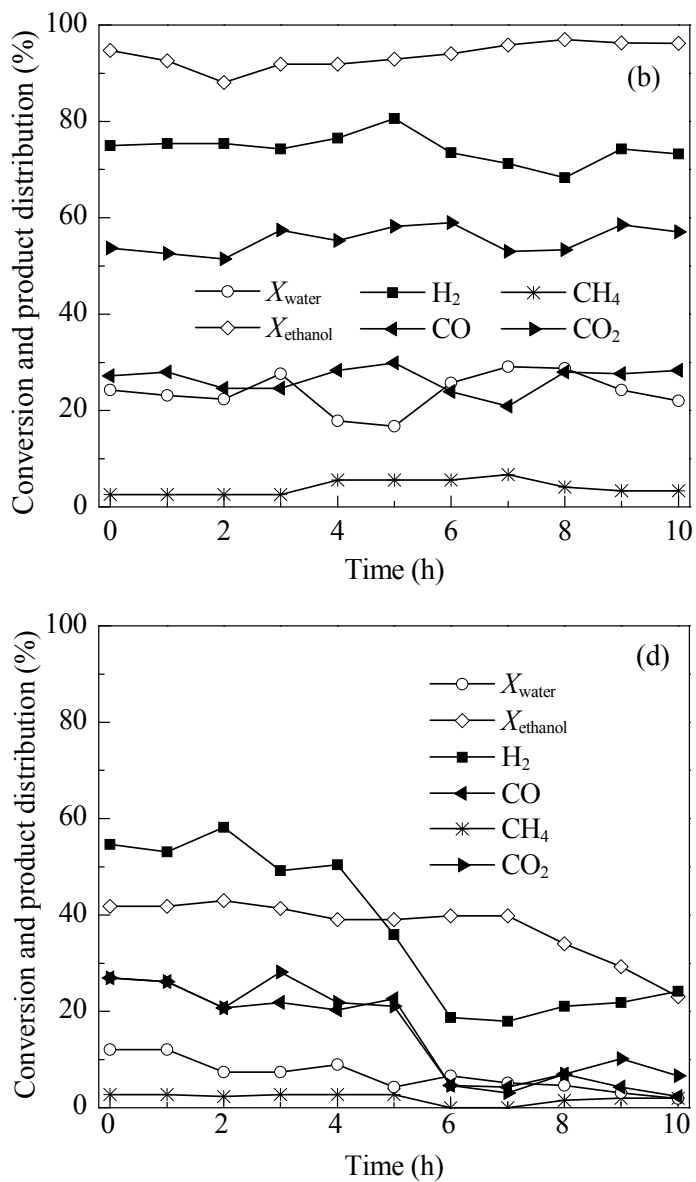

Fig. 6. Ethanol conversion and product distribution versus reaction time on stream at $600{ }^{\circ} \mathrm{C}$. (a) L-Sr-C; (b) L-Ce-C; (c) L-Ca-C; (d) L-Mg-C. 
peak of the Sr-substituted sample exhibited a larger shift. However, in the Mg-substituted sample, the first reduction peak almost disappeared, and the higher-temperature reduction peak shifted to a higher temperature. This is due to the formation of a new phase $\mathrm{MgCo}_{2} \mathrm{O}_{4}$, which makes the reduction of cobalt more difficult.

\subsection{Catalytic performance of catalysts}

The performance of the four catalysts for SRE are shown in Fig. 6, where $X_{\text {ethanol }}$ indicates the ethanol conversion and $X_{\text {water }}$ the water conversion. From Fig. 6, the Sr substitution catalyst exhibited the highest catalytic performance with $100 \%$ ethanol conversion, which did not change during the $10 \mathrm{~h}$ on stream, and the water conversion remained above $30 \%$. The catalytic performance of the Ce-substituted catalyst was slightly lower than that of the Sr substitution sample, with an ethanol conversion of $95 \%$ at $600{ }^{\circ} \mathrm{C}$. However, in the entire test time range, its performance did not decline and even slightly improved, and the water conversion was higher than $20 \%$. The activity of the Ca-substituted sample was significantly lower, with only $50 \%$ ethanol conversion within the first hour, and this decreased with the reaction time, with a final value less than $40 \%$. The Mg-substituted sample showed the lowest activity with an ethanol conversion of only $40 \%$. According to the literature [7], under the same conditions, the ethanol conversion for the La$\mathrm{CoO}_{3}$ catalyst is about $50 \%$. Therefore, the $\mathrm{Sr}$ and Ce-substituted samples provide a more active phase and improve the catalyst performance significantly. The Ca-substituted sample weakened the cobalt-support interaction but did not enhance its activity.

The XRD patterns of the used catalysts for $10 \mathrm{~h}$ are shown in Fig. 7. After the reaction, L-Mg-C and L-Ca-C had a brownmillerite structure, which limits the reduction of the cobalt species in the perovskite, and thereby lowers the activity. The perovskite structure in the L-Ce-C sample was destroyed, leaving the $\mathrm{La}$, $\mathrm{Sr}$, and $\mathrm{Ce}$ as $\mathrm{La}_{2} \mathrm{O}_{2} \mathrm{CO}_{3}, \mathrm{SrCO}_{3}$, and $\mathrm{CeO}_{2}$, respectively. A CoO phase was detected in $\mathrm{L}-\mathrm{Ce}-\mathrm{C}$, but this could not be confirmed in the $\mathrm{L}-\mathrm{Sr}-\mathrm{C}$ sample because of the obscuring diffraction peaks of $\mathrm{SrCO}_{3}$.

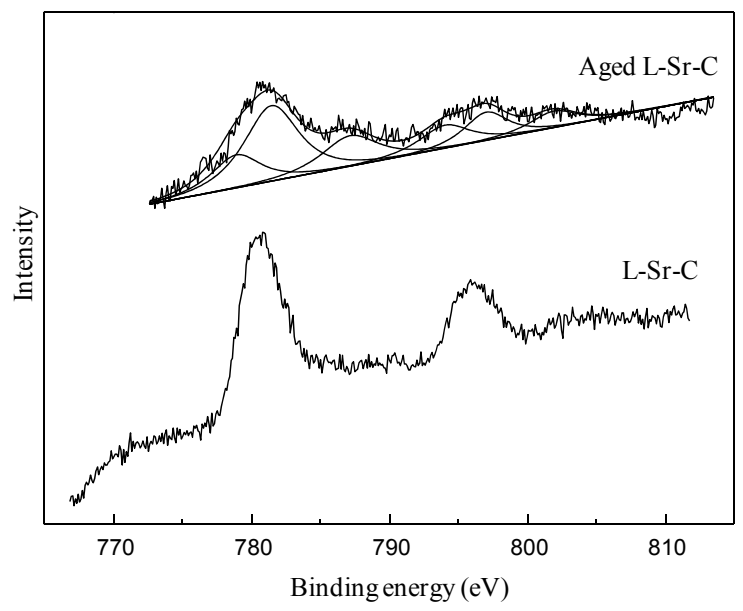

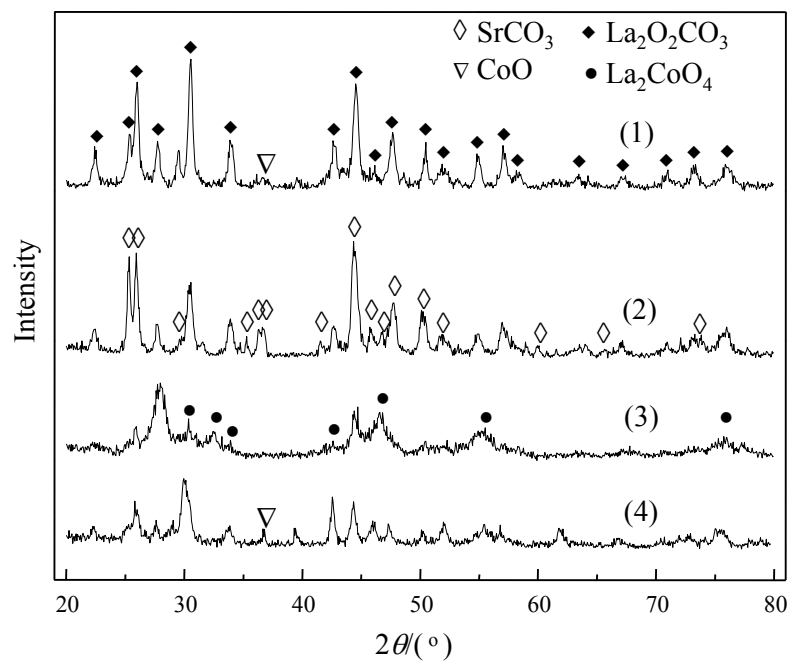

Fig. 7. XRD patterns of the catalysts after aging for $10 \mathrm{~h}$. (1) L-Ce-C; (2) L-Sr-C; (3) L-Ca-C; (4) L-Mg-C.

XPS spectra of the fresh and aged L-Sr-C and L-Ce-C samples are shown in Fig. 8. Co exists in a number of valence states in the aged L-Sr-C sample with Co $2 \mathrm{p}_{3 / 2}$ binding energies of 778.9, 781.4, and 787.1 eV. The peaks at 778.9 and $781.4 \mathrm{eV}$ could be attributed to the $\mathrm{Co}^{0}$ species and the $\mathrm{Co}^{2+}$ shake-up peak, respectively, while the more complex peak at $787.1 \mathrm{eV}$ is due to either $\mathrm{Co}^{2+}$ or $\mathrm{Co}^{3+}$ [17]. However, for the aged L-Ce-C sample, there were only peaks near 781 and $787 \mathrm{eV}$, indicating the presence of $\mathrm{Co}^{2+}$ and the absence of $\mathrm{Co}^{0}$. According to the literature [34], the interaction of $\mathrm{Co}^{0}$ and $\mathrm{Co}^{2+}$ promotes catalytic activity in the SRE reaction, with $\mathrm{Co}^{2+}$ acting as the active center. This would explain why the catalytic performance of L-Sr-C was better than L-Ce-C.

\section{Conclusions}

The four $\mathrm{LaXCoO}_{3}(\mathrm{X}=\mathrm{Mg}$, Ca, Sr, or Ce) catalysts, formed by the substitution of different elements into $\mathrm{LaCoO}_{3}$ at the A site, were prepared and investigated, and their catalytic performance in SRE was also examined. The results showed that the

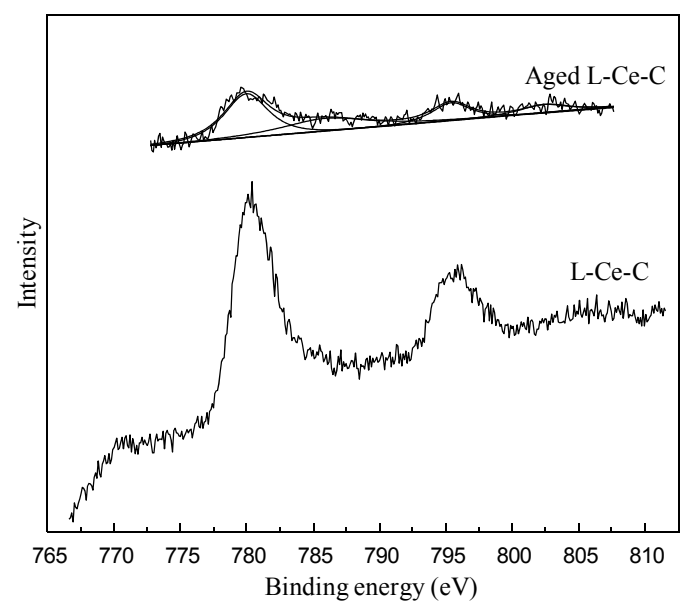

Fig. 8. XPS Co $2 p$ spectra of the two samples after reaction. 


\section{Graphical Abstract}

Chin. J. Catal., 2014, 35: 1768-1778 doi: 10.1016/S1872-2067(14)60182-0

Preparation of $\mathrm{LaXCoO}_{3}(\mathrm{X}=\mathrm{Mg}, \mathrm{Ca}, \mathrm{Sr}, \mathrm{Ce})$ catalysts and their performance for steam reforming of ethanol to hydrogen

Fei Ma, Zhenwu Ding, Wei Chu*, Shixiong Hao, Tao Qi

Sichuan University; Institute of Process Engineering, Chinese Academy of Sciences; Sichuan University of Science and Engineering
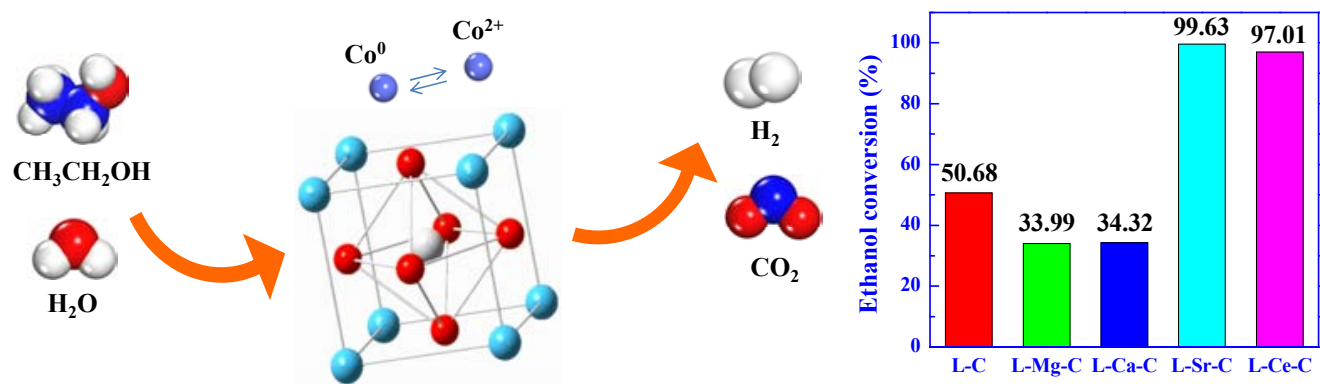

Compared with the perovskite $\mathrm{LaCoO}_{3}$, the Sr-doped or Ce-doped catalyst demonstrated significantly better catalytic performance, while better cobalt reduction enabled the effects.

L-Ce-C sample had a purely perovskite crystal phase, while $\mathrm{L}-\mathrm{Mg}-\mathrm{C}$, L-Ca-C, and $\mathrm{L}-\mathrm{Sr}-\mathrm{C}$ appeared to have some separation phases to different degrees. L-Sr-C and L-Ce-C samples have acicular and bulk crystal phases on the catalyst surface, respectively. Mg substitution strengthened the cobalt-support interaction, making the cobalt reduction more difficult. The Sr and Ce substitution weakened the cobalt-support interaction, which made the cobalt reduction easier. The L-Sr-C sample exhibited the higher activity, with better cobalt reduction, while there was also a separation phase besides the perovskite structure. Both L-Sr-C and L-Ce-C showed high activity and stability in the steam reforming of ethanol. However, the catalytic performance of the former was better.

\section{References}

[1] Tong D G, Chu W, Wu P, Gu G F, Zhang L. J Mater Chem A, 2013, 1: 358

[2] Liu Q H, Liao L W, Liu Z L, Dong X F. J Energy Chem, 2013, 22: 665

[3] Fishtik I, Alexander A, Datta R, Geana D. Int J Hydrogen Energy, 2000, 25: 31

[4] Vizcaíno A J, Carrero A, Calles J A. Catal Today, 2009, 146: 63

[5] Sun J, Wu F, Qiu X P, Wang F, Hao S J, Liu Y. Chin J Catal (孙杰, 吴 锋, 邱新平, 王芳, 郝少军, 刘媛. 催化学报), 2004, 25: 551

[6] Zhang L F, Liu J, Li W, Guo C L, Zhang J L. J Nat Gas Chem, 2009, 18: 55

[7] Ma F, Chu W, Huang L H, Yu X P, Wu Y Y. Chin J Catal (马飞, 储伟, 黄利宏, 余晓鹏, 吴永永. 催化学报), 2011, 32: 970

[8] Pereira E B, Homs N, Martí S, Fierro J L G, de la Piscina P R. J Catal, 2008, 257: 206

[9] Birot A, Epron F, Descorme C, Duprez D. Appl Catal B, 2008, 79: 17

[10] Cai W J, Wang F G, Zhan E S, Van Veen A C, Mirodatos C, Shen W J. J Catal, 2008, 257: 96

[11] He L, Wu Q, Li T M. Nat Gas Chem Ind (何嵧, 吴倩, 李佟芳. 天然气 化工(Cl化学与化工)), 2010, 35(5): 5

[12] Vizcaíno A J, Carrero A, Calles J A. Int J Hydrogen Energy, 2007, 32 : 1450
[13] Frusteri F, Freni S, Spadaro L, Chiodo V, Bonura G, Donato S, Cavallaro S. Catal Commun, 2004, 5: 611

[14] Pang X J, Chen Y Z, Dai R Q Cui P. Chin J Catal (庞潇健, 陈亚中, 代 瑞旗, 崔鹏. 催化学报), 2012, 33: 281

[15] Peng D Q, Liu N, Wang Y H. Chem Engineer (彭得群, 刘宁, 王玉和. 化学工程师), 2008, (1): 7

[16] Petrovic S, Pakic V, Jovanovic D M, Baricevic A T. Appl Catal B, 2006, 66: 249

[17] Balamurugan S, Xu M, Takayama-Muromachi E. J Solid State Chem, 2005, 178: 3431

[18] Hejtmanek J, Jirak Z, Knizek K, Marysko M, Veverka M, Autret C. J Magn Magn Mater, 2008, 320: e92

[19] Murthy P S R, Priolkar K R, Bhobe P A, Das A, Sarode P R, Nigam A K.J Magn Magn Mater, 2011, 323: 822

[20] Magalhães R N S H, Toniolo F S, da Silva V T, Schmal M. Appl Catal A, 2010, 388: 216

[21] Cui M S, Li M L, Zhang S L, Long Z Q Cui D L, Huang X W. Chin J Nonferrous Metal (崔梅生, 李明来, 张顺利, 龙志奇, 崔大立, 黄 小卫. 中国有色金属学报), 2004, 14: 1580

[22] Leontiou A A, Ladavos A K, Armatas G S, Trikalitis P N, Pomonis P T. Appl Catal A, 2004, 263: 227

[23] Seyfi B, Baghalha M, Kazemian H. Chem Eng J, 2009, 148: 306

[24] Bedel L, Roger A C, Rehspringer J L, Zimmermann Y, Kiennemann A. J Catal, 2005, 235: 279

[25] Ding R R, Li C, Wang L J, Hu R S. Appl Catal A, 2013, 464-465: 261

[26] Han X, Yu Y B, He H, Zhao J J. J Energy Chem, 2013, 22: 861

[27] Sun Y, Hla S S, Dffy G J, Cousins A J, French D, Morpeth L D, Edwards J H, Roberts D G. Int J Hydrogen Energy, 2011, 36: 79

[28] Nakamoto K. Infrared and Raman Spectra of Inorganic and Coordination Compounds, Part B, Applications in Coordination, Organometallic, and Bioinorganic Chemistry. 6th Ed. New York: John Wiley \& Sons, 2009. 110

[29] Rao G V S, Rao C N R, Ferraro J R. Appl Spectrosc, 1970, 24: 436

[30] Choi D H, Shim I B, Kim C S, Shaterian M. J Magn Magn Mater, 2008, 320: e575

[31] Salavati-Niasari M, Khansari A, Davar F. Inorg Chim Acta, 2009, 362: 4937

[32] Sharma Y, Sharma N, Subba Rao G V, Chowdari B V R. Solid State 
Ionics, 2008, 179: 587

[33] Stelmachowski P, Maniak G, Kaczmarczyk J, Zasada F, Piskorz W,
Kotarba A, Sojka Z. Appl Catal B, 2014, 146: 105

[34] Hyman M P, Vohs J M. Surf Sci, 2011, 605: 383

\title{
$\mathrm{LaXCoO}_{3}(\mathrm{X}=\mathrm{Mg}, \mathrm{Ca}, \mathrm{Sr}, \mathrm{Ce})$ 催化剂的制备及其催化乙醇水蒸气重整制氢
}

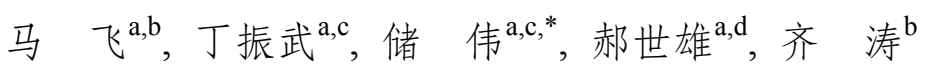 \\ ${ }^{a}$ 四川大学化工学院, 四川成都610065 \\ ${ }^{b}$ 中国科学院过程工程研究所湿法冶金清洁技术国家工程实验室，北京 100190 \\ ' 四川省环境保护环境催化材料工程技术研究中心, 四川成都610064 \\ $\mathrm{d}$ 四川理工学院化工系, 四川自贡643000
}

\begin{abstract}
摘要: 以PEG 400为分散剂, 采用一步柠檬酸络合法制备了 $\mathrm{LaXCoO}_{3}(\mathrm{X}=\mathrm{Mg}, \mathrm{Ca}, \mathrm{Sr}, \mathrm{Ce} ; \mathrm{La}: \mathrm{X}=3: 2)$ 复合催化剂. 采用X射线衍 射、红外光谱、扫描电镜、 $X$ 射线光电子能谱、 $\mathrm{N}_{2}$ 吸附-脱附和 $\mathrm{H}_{2}$ 程序升温还原等技术对复合催化剂进行了表征, 考察了不同元 素A位取代对 $\mathrm{LaCoO}_{3}$ 钻钣矿结构的影响, 进而研究了其对乙醇水蒸气重整制氢的催化性能和稳定性. 结果表明, 在高含量取代时, 只有 $\mathrm{Ce}$ 取代的样品能够保持单一的钻钛矿晶型; $\mathrm{Ca}$ 或 $S r$ 取代的样品产生的 $\mathrm{Co}_{3} \mathrm{O}_{4}$ 分离相有利于复合催化剂活性中心钴的还原; $\mathrm{Sr}$ 或Ce取代的样品在反应中表现出较好的活性和稳定性, Sr取代的样品活性更高.
\end{abstract}

关键词: 柠檬酸络合法; 钻钛矿; 钴; 复合催化剂; 乙醇水蒸气重整; 氢气

收稿日期: 2014-04-25. 接受日期: 2014-06-28. 出版日期: 2014-10-20.

*通讯联系人. 电话：(028)85403836; 传真：(028)85461108; 电子信箱：chuwei1965scu@163.com, chuwei1965@scu.edu.cn 基金来源: 国家重点基础研究发展计划(973计划, 2011CB201202).

本文的英文电子版由Elsevier出版社在ScienceDirect上出版(http://www.sciencedirect.com/science/journal/18722067).

\section{1. 前言}

氢气作为一种高效、清洁的能源 ${ }^{[1,2]}$, 被认为是解决 21 世纪人类社会能源危机的新能源之一. 特别是随着以 氢气为原料的燃料电池及燃料电池汽车的快速发展, 预 计未来对氢能源的需求会逐渐增大. 目前工业上氢气主 要来源于化石燃料重整和电解水, 然而前者仍以消耗化 石能源为代价, 后者能耗较高, 因此在应用方面受到一 定的限制. 低碳醇重整制取氢因其高产氢比而成为广泛 研究对象, 乙醇水蒸气重整制氢(SRE) 更是因其原料含 $10 \%(\mathrm{v} / \mathrm{v})$ 左右的生物质乙醇, 可直接从工业得到不需蒸 馏浓缩而备受关注. 该反应过程可表示如下:

\section{$\mathrm{CH}_{3} \mathrm{CH}_{2} \mathrm{OH}+3 \mathrm{H}_{2} \mathrm{O} \rightarrow 6 \mathrm{H}_{2}+2 \mathrm{CO}_{2} \quad \Delta H^{\mathrm{e}}{ }_{298}=347.4 \mathrm{~kJ} / \mathrm{mol}$}

该反应过程为吸热反应 ${ }^{[3]}$, 存在一系列复杂的副反 应生成乙醛、丙酮、乙烯、CO和积碳等 ${ }^{[4]}$, 因此选择具 有高活性、高选择性和高稳定性的催化剂是整个乙醇制 氢过程中的关键. 据文献报道, 含有 $\mathrm{Ni}^{[5,6]} 、 \mathrm{Co}^{[7,8]}$ 和贵金 属 ${ }^{[9,10]}$ 的催化剂在SRE反应中表现出较好的活性和选择 性. 以 $\mathrm{Ni}$ 为活性中心的催化剂对乙醇中 $\mathrm{C}-\mathrm{C}$ 键和 $\mathrm{C}-\mathrm{H}$ 键 断裂表现出很强的活性, 但积碳现象严重; 而Co基催化 剂表现出优异的重整性能. 因此, 人们对不同载体负载 的 $\mathrm{Co}$ 基催化剂进行了广泛研究, 包括 $\mathrm{Al}_{2} \mathrm{O}_{3}{ }^{[11]}, \mathrm{SiO}_{2}{ }^{[12]}$, $\mathrm{MgO}^{[13]}, \mathrm{CeO}_{2}{ }^{[14]}$ 和 $\mathrm{La}_{2} \mathrm{O}_{3}{ }^{[15]}$ 等. 研究表明, 以 $\mathrm{CeO}_{2}$ 或 $\mathrm{La}_{2} \mathrm{O}_{3}$ 为载体的催化剂都表现出较好的活性并且得到了
理想的反应产物. 然而, Co 基催化剂稳定性不高, 在应 用上还存在很大挑战. 高温时金属Co粒子的烧结和积 碳对催化剂稳定性的影响非常大; Co 含量越高, 烧结越 严重. 稀土载体表面的元素能与 $\mathrm{CO}_{2}$ 发生反应生成碳酸 盐, 可消除积碳 ${ }^{[7]} ; \mathrm{CeO}_{2}$ 能够产生晶格氧, 并与表面积碳 发生反应. 因此, 载体的选择同样对SRE反应影响很大.

钙铁矿 $\mathrm{ABO}_{3}$ 因其稳定性而在很多反应中表现出非 常好的催化活性, 且在SRE反应中也具有一定的催化活 性, 但锝铁矿中用作活性中心的金属量有限. 因此, 最大 限度地利用钙铁矿中的金属比较困难. 钙铁矿结构中 $\mathrm{A}$ 位用其他元素(碱金属或稀土元素)部分取代形成 $\mathrm{A}_{1-x} \mathrm{~A}_{x} \mathrm{BO}_{3}$, 可以改变 $\mathrm{B}$ 位离子的氧化状态以及阳离子缺 陷密度和氧空位量, 从而间接影响 $\mathrm{ABO}_{3}$ 钻铁矿的催化 性能.

钙铁矿型 $\mathrm{LaCoO}_{3}$ 催化剂材料应用于乙醇水蒸气重 整反应时具有低 $\mathrm{CH}_{4}$ 和 $\mathrm{CO}$ 选择性的优势, 但是单一的 $\mathrm{LaCoO}_{3}$ 钻铁矿的活性还远不够, 适当的 $\mathrm{A}$ 位或者 $\mathrm{B}$ 位取 代能够提高其催化性能 ${ }^{[16-20]}$. 崔梅生等 ${ }^{[21]}$ 发现掺入 $\mathrm{Ce}$ 的 $\mathrm{LaCoO}_{3}$ 可明显提高其催化甲烷燃烧反应活性. 用 $\mathrm{Sr}$ 取代的 $\mathrm{La}_{1-x} \mathrm{Sr}_{x} \mathrm{MO}_{3}(0<x<0.4, \mathrm{M}=\mathrm{La}, \mathrm{Ca}, \mathrm{Fe})$ 在甲烷 燃烧反应中的催化活性可与贵金属催化剂 $0.5 \mathrm{wt} \%$ $\mathrm{Pt} / \mathrm{Al}_{2} \mathrm{O}_{3}$ 媲美 ${ }^{[22]}$. 而 $\mathrm{Cu}$ 取代的钻铁矿 $\mathrm{LaCo}_{1-x} \mathrm{Cu}_{x} \mathrm{O}_{3-\delta}$ 在低 碳醇合成反应中的催化性能也有显著提高 ${ }^{[23]}$. Bedel

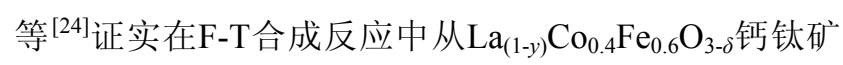


还原出来的金属Co的最大量可达 $2.1 \%$. 马飞等 ${ }^{[7]}$ 研究的 $\mathrm{Zn}$ 掺杂的 $\mathrm{LaCoO}_{3}$ 钙钛矿显著提高了其催化SRE反应活 性.

本文制备了四种金属离子取代 $\mathrm{LaCoO}_{3}$ 钻钛矿 $\mathrm{A}$ 位 而得到的 $\mathrm{LaXCoO}_{3}(\mathrm{X}=\mathrm{Mg}, \mathrm{Ca}, \mathrm{Sr}, \mathrm{Ce})$ 系列钻钛矿结构 催化剂, 并通过X射线衍射(XRD)、红外光谱(FT-IR)、扫 描电镜(SEM)、X射线光电子能谱(XPS)、 $\mathrm{N}_{2}$ 吸附-脱附 (BET) 和 $\mathrm{H}_{2}$ 程序升温还原 $\left(\mathrm{H}_{2}-\mathrm{TPR}\right)$ 等技术进行了表征, 考察了催化剂在SRE反应中的催化性能及其稳定性.

\section{2. 实验部分}

\section{1. 催化剂的制备}

采用柠檬酸络合法制备 $\mathrm{LaXCoO}_{3}(\mathrm{X}=\mathrm{Mg}, \mathrm{Ca}, \mathrm{Sr}, \mathrm{Ce})$ 钙铁矿复合催化剂, 用 $\mathrm{La}\left(\mathrm{NO}_{3}\right)_{3} \cdot 6 \mathrm{H}_{2} \mathrm{O}, \mathrm{Mg}\left(\mathrm{NO}_{3}\right)_{2} \cdot 6 \mathrm{H}_{2} \mathrm{O}$, $\mathrm{Ca}\left(\mathrm{NO}_{3}\right)_{2} \cdot 4 \mathrm{H}_{2} \mathrm{O}, \quad \mathrm{Sr}\left(\mathrm{NO}_{3}\right)_{2} \cdot 4 \mathrm{H}_{2} \mathrm{O}, \quad \mathrm{Ce}\left(\mathrm{NO}_{3}\right)_{3} \cdot 6 \mathrm{H}_{2} \mathrm{O}$, $\mathrm{Co}\left(\mathrm{NO}_{3}\right)_{2} \cdot 6 \mathrm{H}_{2} \mathrm{O}$ 和柠檬酸作为反应试剂. 首先将按计量比 $(n(\mathrm{La}+\mathrm{X}): n \mathrm{Co}=1, n(\mathrm{La}): n(\mathrm{X})=3: 2)$ 的金属硝酸盐溶解 在去离子水中, 将金属总摩尔量 1.2 倍的柠檬酸溶解在另 一个烧杯中, 加入 0.2 倍柠檬酸摩尔量的PEG 400 , 然后 把金属盐溶液逐滴加到柠檬酸溶液, 在 $80^{\circ} \mathrm{C}$ 常压下摚拌 蒸发至形成胶状. 将胶状物于 $120^{\circ} \mathrm{C}$ 干燥 $24 \mathrm{~h}$, 形成的疏 松海绵状固体于 $750{ }^{\circ} \mathrm{C}$ 焙烧 $3 \mathrm{~h}$, 得到催化剂样品 $\mathrm{LaCoO}_{3}, \mathrm{La}_{0.6} \mathrm{Mg}_{0.4} \mathrm{CoO}_{3}, \mathrm{La}_{0.6} \mathrm{Ca}_{0.4} \mathrm{CoO}_{3}, \mathrm{La}_{0.6} \mathrm{Sr}_{0.4} \mathrm{CoO}_{3}$ 和 $\mathrm{La}_{0.6} \mathrm{Ce}_{0.4} \mathrm{CoO}_{3}$, 分别 记为 L-C, L-Mg-C, L-Ca-C, L-Sr-C和L-Ce-C.

\section{2. 催化剂的表征}

采用飞利浦X'pert pro MPD型XRD仪分析催化剂的 晶相, $\mathrm{Cu} K_{\alpha}$ 射线, 石墨单色器, 管电压 $40 \mathrm{kV}$, 管电流 50 $\mathrm{mA}$, 测试范围 $2 \theta=20^{\circ}-80^{\circ}$. 采用德国 Bruker 公司的 TENSOR 27型红外光谱仪测定催化剂的FT-IR谱. 将 15 $\mathrm{mg}$ 样品用 100 倍的 $\mathrm{KBr}$ 稀释, 研磨混合均匀后压片, 然后 在室温下进行测试, 扫描范围400-4000 $\mathrm{cm}^{-1}$.

催化剂的形貌采用Hitachi公司的S-3400型FE-SEM 进行分析, 加速电压 $20 \mathrm{kV}$.

采用英国Kratos公司的XSAM800型能谱仪对催化 剂表面元素进行分析. 激发光源采用 $\mathrm{Al} K_{\alpha}$ 射线 $(h v=$ $1486.6 \mathrm{eV})$, 样品的电荷效应以 $\mathrm{C} 1 s(284.6 \mathrm{eV})$ 为内标加 以校正.

催化剂的比表面积和孔性质采用美国康塔公司的 NOVA 1000e型比表面积和孔径分布测定仪测量. 催化 剂装量为 $200 \mathrm{mg}$, 在 $-196^{\circ} \mathrm{C}$ 时测定 $\mathrm{N}_{2}$ 的吸附-脱附曲线, 利用BET公式求得催化剂的比表面积, 用BJH方法求得
孔径分布.

催化剂的还原性能用TPR实验进行测量. 样品用量 为 $50 \mathrm{mg}$, 还原气为 $5 \% \mathrm{H}_{2} / \mathrm{N}_{2}$ 混合气, 升温速率 $10{ }^{\circ} \mathrm{C} / \mathrm{min}$. 采用SC-200型气相色谱仪热导检测器(TCD)对床层出口 的尾气进行在线分析.

\section{3. 催化剂的评价}

催化剂评价在微型固定床石英反应器上进行, 每次 装入 $100 \mathrm{mg}$ 催化剂(60-80目)和800 mg石英砂(40-60目) 的混合样品, 用 $5 \mathrm{vol} \% \mathrm{H}_{2} / \mathrm{Ar}$ 混合气在特定温度下还原. 还原后在氮气吹扫下降至最初反应温度, 通入乙醇水混 合溶液 $\left(n\left(\mathrm{H}_{2} \mathrm{O}\right) / n\left(\mathrm{C}_{2} \mathrm{H}_{5} \mathrm{OH}\right)=6\right)$ 和 $\mathrm{N}_{2}$, 溶液流量为 4.8 $\mathrm{mL} / \mathrm{h}$, 用DDB-300型电子蠕动百打入汽化室并于 $150{ }^{\circ} \mathrm{C}$ 汽化, $\mathrm{N}_{2}$ 流量为 $60 \mathrm{~mL} / \mathrm{min}$, 总的空速为 $50000 \mathrm{~h}^{-1}$. 在 $600{ }^{\circ} \mathrm{C}$ 下连续反应 $10 \mathrm{~h}$ 以考察催化剂的反应活性. 采用 SC-200型气相色谱仪 TCD 在线分析反应产物. $\mathrm{H}_{2}, \mathrm{~N}_{2}$, $\mathrm{CO}, \mathrm{CO}_{2}$ 和 $\mathrm{CH}_{4}$ 等永久性气体用 TDX-01分子篎柱分离, 以 $30 \mathrm{~mL} / \mathrm{min}$ 高纯 $\mathrm{Ar}$ 为载气; $\mathrm{H}_{2} \mathrm{O}$ 、乙醇、乙醛和丙酮等 产物用Porapak-Q柱分离.

\section{3. 结果与讨论}

\section{1. 催化剂的物相结构和表面元素分析}

\subsection{1. 催化剂的物相分析}

图1为不同元素取代 $\mathrm{A}$ 位的钙钛矿型样品的XRD谱. 所有样品都出现了 $\mathrm{LaCoO}_{3}$ 斜方晶体的特征衍射峰, 但只 有 $\mathrm{Ce}$ 取代的 $\mathrm{LaCoO}_{3}$ 表现出单一的钙钛矿晶相. $\mathrm{Mg}$ 取代 的样品在 $2 \theta=34.3^{\circ}$ 和 $62.5^{\circ}$ 处出现 $\mathrm{MgCo}_{2} \mathrm{O}_{4}$ 的特征峰; $\mathrm{Ca}$ 和 $\mathrm{Sr}$ 取代的样品在 $2 \theta=31.3^{\circ}, 36.8^{\circ}$ 及 $65.7^{\circ}$ 处出现 $\mathrm{Co}_{3} \mathrm{O}_{4}$ 的特征峰; 而 $\mathrm{Sr}$ 取代的样品还出现了镧的氧化物 及碳酸盐等杂相. 图1还示出了不同元素对钻钛矿的取 代导致其特征峰的移动情况. 相对于 $2 \theta=33^{\circ}$ 附近的钙 钛矿特征峰, $\mathrm{Mg}, \mathrm{Ca}$ 和 $\mathrm{Sr}$ 取代的样品向低角度偏移 $0.1^{\circ}$, $\mathrm{Ce}$ 取代的样品则向高角度偏移 $0.3^{\circ}$, 表明不同元素取代 均对钙铁矿结构有影响, 其中以Ce取代影响较大.

根据实验结果计算了样品的晶胞参数, 如表 1 所示. 相对于 L-C样品的晶胞参数 $(0.5436 \mathrm{~nm}), \mathrm{Mg}, \mathrm{Ca}$ 和 $\mathrm{Sr}$ 取 代样品的略有变化, 而 $\mathrm{Ce}$ 取代的样品减少了 $0.0017 \mathrm{~nm}$. 然而就离子半径而言, $\mathrm{Mg}^{2+}(0.068 \mathrm{~nm})$ 和 $\mathrm{Ca}^{2+}(0.0118$ $\mathrm{nm})$ 均小于 $\mathrm{La}^{3+}(0.136 \mathrm{~nm}) ; \mathrm{Ce}^{3+}(0.134 \mathrm{~nm})$ 与 $\mathrm{La}^{3+}$ 的基本 相当; $\mathrm{Sr}^{2+}(0.144 \mathrm{~nm})$ 大于 $\mathrm{La}^{3+}$. 由于离子半径不同, 取代 元素进入到钻钛矿晶格之中会导致晶胞参数的差 异 ${ }^{[25,26]}$. 尽管 $\mathrm{Mg}^{2+}$ 和 $\mathrm{Ca}^{2+}$ 的离子半径远小于 $\mathrm{La}^{3+}$, 但取代 样品的晶胞参数和 L-C 差距很小, 且分别检测到 
$\mathrm{MgCo}_{2} \mathrm{O}_{4}$ 相和 $\mathrm{Co}_{3} \mathrm{O}_{4}$ 相, 表明 $\mathrm{Mg}$ 或 $\mathrm{Ca}$ 的添加没有影响 $\mathrm{LaCoO}_{3}$ 钙钛矿晶格. 而 $\mathrm{Ce}$ 取代的样品只出现单一的晶 相, 表明 $\mathrm{Ce}$ 完全进入钙钛矿主体; 离子半径相近和相似 的性质可以解释实验现象 ${ }^{[27]}$. Sr取代的样品则表现出多 种物相共存. 为了进一步分析取代对钙钛矿结构和性质 的影响, 进一步对样品进行了表征.

图 2 为 $\mathrm{A}$ 位离子用不同元素取代的催化剂样品的 FT-IR谱. 在 600 和 $420 \mathrm{~cm}^{-1}$ 附近的两个强峰分别归属于 典型的 $\mathrm{LaCoO}_{3}$ 钙钛矿中 $\mathrm{Co}-\mathrm{O}$ 六面体中的 $\mathrm{Co}-\mathrm{O}$ 伸缩振 动 ${ }^{[28]}$ 和 $\mathrm{O}-\mathrm{Co}-\mathrm{O}$ 弯曲振动 ${ }^{[29]}$. 由图可见, 所有样品都形 成了这种结构. L-Ca-C和L-Sr-C样品在 $670 \mathrm{~cm}^{-1}$ 处出现 红外峰, 对应于四面体结构中的 $\mathrm{Co}^{2+}$ 形成的 $\mathrm{M}-\mathrm{O}$ 的伸缩 振动 ${ }^{[30]}$. 可以推测这种 $\mathrm{Co}^{2+}$ 来源于 $\mathrm{Co}_{3} \mathrm{O}_{4}{ }^{[31]}$, 与 $\mathrm{XRD}$ 结 果一致. L-Sr-C样品还在 1470 和 $814 \mathrm{~cm}^{-1}$ 处出现 $\mathrm{CO}_{3}{ }^{2-}$ 中 的特征振动峰 $\left(\mathrm{C}-\mathrm{O}\right.$ 伸缩振动 $1476 \mathrm{~cm}^{-1}, \mathrm{C}-\mathrm{O}$ 弯曲振动 $\left.844 \mathrm{~cm}^{-1}\right)$, 表明在 $\mathrm{Sr}$ 取代的样品中有碳酸盐, 与 XRD结 果一致. 还可以看到, 相对于 $\mathrm{LaCoO}_{3}$ 钻钛矿在 $600 \mathrm{~cm}^{-1}$ 附近的振动峰, $\mathrm{Ca}, \mathrm{Mg}, \mathrm{Sr}$ 和 $\mathrm{Ce}$ 取代的样品振动峰红移, 且 Ce取代样品的偏移量较 $\mathrm{Ca}$ 和 $\mathrm{Sr}$ 取代样品的大.

五个样品的比表面积列于表1. 可见各样品的比表 面积均不足 $10 \mathrm{~m}^{2} / \mathrm{g}$, 这是由于形成钙钛矿结构所需的高 温 $\left(750^{\circ} \mathrm{C}\right)$ 烧结造成的. $\mathrm{Mg}$ 取代样品的比表面积最小 $\left(3.3 \mathrm{~m}^{2} / \mathrm{g}\right)$, Ca和 $\mathrm{Sr}$ 取代的样品略高于L-C样品 $\left(8.3 \mathrm{~m}^{2} / \mathrm{g}\right)$, Ce取代样品为 $6.8 \mathrm{~m}^{2} / \mathrm{g}$.

\subsection{2. 催化剂的表面形貌}

图3为各取代样品的SEM照片. 可以看出, $\mathrm{Mg}$ 和 $\mathrm{Ca}$ 取代样品的表面形貌和 L-C样品类似, 但 $\mathrm{Mg}$ 取代的样品 更加致密, 因而比表面积较小; 而Sr和Ce取代的样品表 面有类似于L-C钙钛矿的结构, 且分别出现了针状和块 状晶相, 镶嵌在主体钙钛矿结构上, 可以直观地看到 $\mathrm{Ce}$ 和 $\mathrm{Sr}$ 取代对钙铁矿结构的影响.

\subsection{3. 催化剂表面元素分析}

图4为五个催化剂的Co $2 p$ XPS谱. 取代样品显示出 类似于 $\mathrm{LaCoO}_{3}$ 钙钛矿的XPS谱. 为了研究催化剂中 $\mathrm{Co}$ 物种被不同元素取代后 Co 价态的变化, 表2列出了 Co $2 p_{3 / 2}$ 的结合能. 相对于L-C样品, 取代的样品都向高结合 能方向偏移, 表明 $\mathrm{Co}$ 的价态有所变化 ${ }^{[18]} . \mathrm{MgCo}_{2} \mathrm{O}_{4}$ 中的 $\mathrm{Co}^{3+}$ 结合能为 $780.8 \mathrm{eV}^{[32,33]}, \mathrm{Mg}$ 取代后的钙钛矿偏移值 最大, 为 $0.8 \mathrm{eV}$, 这主要是由于出现的分离相 $\mathrm{MgCo}_{2} \mathrm{O}_{4}$ 所 致. 同样地, 出现分离相 $\mathrm{Co}_{3} \mathrm{O}_{4}$ 的 $\mathrm{Ca}$ 和 $\mathrm{Sr}$ 取代的样品也表 现出较大的偏移量, 为 $0.6 \mathrm{eV}$. Ce取代的偏移最小, 为 0.3 $\mathrm{eV}$, 这是由于 $\mathrm{Ce}$ 主要以 +3 价形式存在, 与 $\mathrm{LaCoO}_{3}$ 中 $\mathrm{La}$ 的
价态相同, 但其本身存在 +4 价和 +3 价相互转换, 其结合 能也略高于纯的 $\mathrm{LaCoO}_{3}$ 钙钛矿 ${ }^{[32]}$. 通过 $\mathrm{Co} / \mathrm{La}$ 比发现, $\mathrm{Sr}$ 和Ce取代能够增加钙铁矿表面的Co含量, 有利于在 SRE反应中表现出较高的催化活性.

\subsection{TPR结果}

图 5 为五个样品的 $\mathrm{H}_{2}-\mathrm{TPR}$ 谱. 由图可知, 除了 $\mathrm{Mg}$ 取 代的样品, 其他样品都有低温和高温两个还原峰. 相对 于L-C样品, $\mathrm{Ca}, \mathrm{Sr}$ 和Ce取代的样品的第一个还原峰均向 低温发生偏移, 表明它们的取代削弱了钙钛矿结构中 La-O-Co的作用, 从而有利于Co的还原, 其中以 Sr取代 样品的第一个还原峰向低温方向偏移最大, 该峰可归属 为部分 $\mathrm{Co}^{3+}$ 还原为 $\mathrm{Co}^{2+[33]}$. 而 $\mathrm{Mg}$ 取代样品的第一个还 原峰几乎消失, 可归结于 $\mathrm{Mg}$ 的加入形成了新的 $\mathrm{MgCO}_{2} \mathrm{O}_{4}$ 相, 使Co很难被还原.

\section{3. 催化剂在SRE反应中的催化性能}

图6为四种不同元素取代的 $\mathrm{LaCoO}_{3}$ 催化剂上SRE反 应活性, 其中 $X_{\text {ethanol }}$ 和 $X_{\text {water }}$ 分别表示乙醇转化率和水的 转化率. 由图可知, $\mathrm{Sr}$ 取代的催化剂上, 乙醇转化率能达 到 $100 \%$, 且可保持 $10 \mathrm{~h}$ 而活性几乎没有下降, 水转化率 达到了 $30 \%$ 以上; Ce取代样品的活性略低于 $\mathrm{Sr}$ 取代样 品, $600{ }^{\circ} \mathrm{C}$ 时乙醇不能达到完全转化, 最大只能达到 95\%, 但在整个测试范围活性没有下降, 反而呈上升趋 势, 水转化率高于 $20 \%$; $\mathrm{Ca}$ 取代的样品活性较低, 在最初 的 $1 \mathrm{~h}$ 内乙醇转化率只有 $50 \%$, 且随着时间的增加明显下 降, 最终仅为 $40 \%$; $\mathrm{Mg}$ 取代的样品活性最低, 整个过程 中乙醇最大转化率只有 $40 \%$. 而据文献[7], 在相同条件 下, $\mathrm{LaCoO}_{3}$ 催化剂对乙醇的转化率为 $50 \%$ 左右. 由此表 明, $\mathrm{Sr}$ 或Ce取代样品后能够产生较多的活性相, 可以显 著提高催化剂活性; $\mathrm{Ca}$ 的取代对催化剂活性影响不大; 而 $\mathrm{Mg}$ 的取代则降低了样品活性.

图7为反应后各催化剂的XRD谱. 可以看到, $\mathrm{Mg}$ 和 $\mathrm{Ca}$ 取代的样品在反应后仍存在钙铁石等结构, 不利于铻 钛矿中钴物种的还原, 因而催化活性较低. 反应后的 $\mathrm{Sr}$ 或 $\mathrm{Ce}$ 取代样品中钙钛矿结构遭到破坏, $\mathrm{La}$ 主要以 $\mathrm{La}_{2} \mathrm{O}_{2} \mathrm{CO}_{3}$ 形式存在, $\mathrm{Sr}$ 主要以 $\mathrm{SrCO}_{3}$ 形式存在, $\mathrm{Ce}$ 主要以 $\mathrm{CeO}_{2}$ 形式存在. 在 $\mathrm{Ce}$ 取代的样品中检测到了 $\mathrm{CoO}$ 相; 而 在该位置由于 $\mathrm{SrCO}_{3}$ 的衍射峰比较强, 不能证明在 $\mathrm{Sr}$ 取 代的样品中同样存在 $\mathrm{CoO}$ 相.

图 8 为 $\mathrm{Sr}$ 或 $\mathrm{Ce}$ 取代样品反应前后的XPS谱. 可以看 出, 反应后的 $\mathrm{Sr}$ 取代样品中Co以多种价态形式存在, Co $2 p_{3 / 2}$ 的结合能分别是 $778.9,781.4$ 和 $787.1 \mathrm{eV}$. 前两者可 分别归属于 $\mathrm{Co}^{0}$ 和 $\mathrm{Co}^{2+}$ 的摇摆振动峰, 而 $781.4 \mathrm{eV}$ 处的峰 
比较复杂, 既可能是 $\mathrm{Co}^{2+}$ 也可能是 $\mathrm{Co}^{3+}$ 的峰. 而反应后 $\mathrm{Ce}$ 取代的样品只在 781 和 $787 \mathrm{eV}$ 附近出现峰, 表明 Co主 要是以 $\mathrm{Co}^{2+}$ 存在. 研究表明 ${ }^{[34]}, \mathrm{Co}^{0}$ 与 $\mathrm{Co}^{2+}$ 相互作用能够 促进SRE反应活性, $\mathrm{Co}^{2+}$ 也是活性中心之一. 因此, $\mathrm{Sr}$ 取 代的样品活性比Ce取代样品的高.

\section{4. 结论}

研究了 $\mathrm{Mg}, \mathrm{Ca}, \mathrm{Sr}$ 和 $\mathrm{Ce}$ 在 $\mathrm{A}$ 位取代 $\mathrm{LaCoO}_{3}$ 形成 $\mathrm{LaXCoO}_{3}$ 对铂钛矿结构的影响, 考察了催化剂在乙醇水 蒸气重整制氢反应中的催化活性. Ce取代的样品能够
得到单一的钙钛矿晶型, 没有观察到分离相; 而 $\mathrm{Mg}, \mathrm{Ca}$ 和 $\mathrm{Sr}$ 取代的样品在不同程度上出现了分离相. $\mathrm{Mg}$ 取代 的样品形成了致密的钻钠矿形态, $\mathrm{Sr}$ 或 $\mathrm{Ce}$ 取代的样品在 催化剂表面呈现针状或片状的分离相. $\mathrm{Mg}$ 取代的样品 增强了钙钛矿中钴的相互作用, 不利于 $\mathrm{Co}$ 物种的还原. 而 $\mathrm{Ca}, \mathrm{Sr}$ 和 $\mathrm{Ce}$ 取代削弱了钙钛矿中钴的结合程度, 有利 于 $\mathrm{Co}$ 物种的还原; $\mathrm{Sr}$ 取代的样品由于其分离相的影响, 表现出了更优的Co还原性能. 在乙醇水蒸汽重整反应 中 Sr或Ce取代的样品表现出了较高的活性和稳定性, 其 中以 $\mathrm{Sr}$ 取代的更优. 